\title{
三菱コータ高速化への取組み*
}

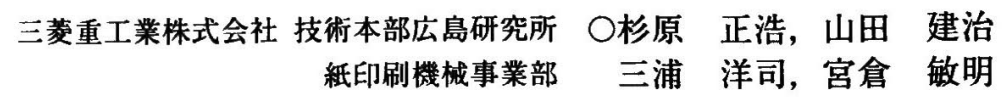

\section{Development of Mitsubishi High Speed Coater}

\section{Masahiro Sugihara and Kenji Yamada}

Mitsubishi Heavy Industries. LTD. Hiroshima R\&D Center

Hiroshi Miura and Toshiaki Miyakura

Mitsubishi Heavy Industries, LTD. Paper \& Printing Machinery Division

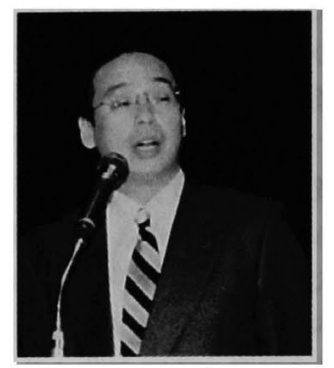

杉原正浩

Mitsubishi Pilot Coater has been rebuilt to improve highspeed coating performance. This rebuild enables our high-speed coating technology developments, fundamental studies on high-speed coating phenomena, and customer's highspeed coating trials which verify the performance of coater or coating color composition.

The state of the art "Ejector \& Steam substitution System" for high-speed free jet type applicator, which prevents the air entrainment at the interface between coating color jet and base paper surface, has been developed by using this high-speed pilot coater. Fundamental studies on film splitting and misting phenomena are also carrying out to realize the high-speed film coater.

In this report, we present our new high-speed pilot coater and some new technologies for highspeed coating.

分類 : $N_{3}$ 渗工機, $S_{5}$ 塗工印刷用紙（微塗工印刷用紙含む）

\section{1.はじめに}

最近のコート紙市場では, オンデマンド印刷機, パ ソコン, 携带電話といったIT 機器の急速な普及に伴 うカタログ, 取扱説明書用紙の需要增大と, パソコン 雑読等の情報量增加に伴う增ページに伴って, 塗工速 度の增加と軽量・微塗工化が進みつつある。

このような動向に対応すべく，当社ではパイロット コータの增速とレイアウト変更を行った。これにより, 各種塗工装置, 塗工液の高速塗工性能検証・評価など, 各種ニースに合ったトライアルが実施可能となった。

*平成 12 年度年次大会講演（講演 No. A 20)
また著者らは，この高速パイロットコータを用いて， ロッドメタリンク，ゲートロールなどピグメント塗工 用フィルムコータ, S-Flow などフリージェット型ブ レードコータ, 及びカーテンフローコータの高速化に 向けた，様々な技術開発を行っている。

本報では，上述の三菱パイロットコータ高速化改造 の概要, 運転経験, 及び各種コータの高速化技術開発 状況について述べる。

\section{2. 紙コータに関する最近の動向}

前章で述べたように, コート紙の生産速度は年々高 速化する傾向を示している。図 1 は, 当社が納入した 紙コータの設計速度実績を示したものである。この図 
に示されるように、コー夕設計速度は 1970 年頃には $1,000 \mathrm{~m} / \mathrm{min}$ 程度であったものが, 最近では $1,600 \mathrm{~m}$ $/ \mathrm{min}$ まで増加しており, 近い将来 $2,000 \mathrm{~m} / \mathrm{min}$ に達 するものと予測される（図 1)。

一方で, パソコン, 携帯電話などの取扱い説明書,

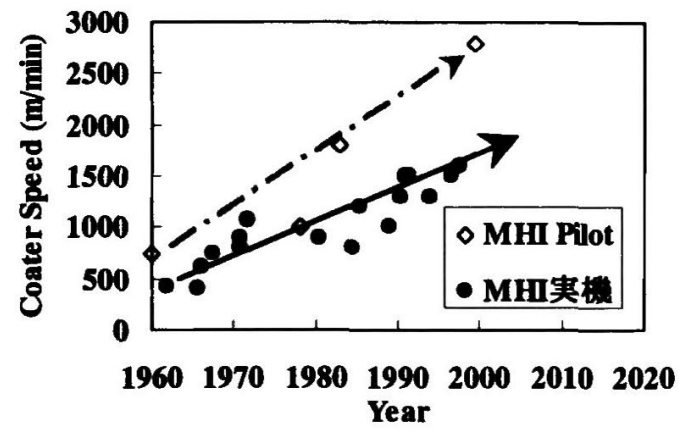

図 1 コータ設計速度の変遷

Text Tonnage Breakout by Basis Weight (per 3,300 $\mathrm{tt}^{2}$ )

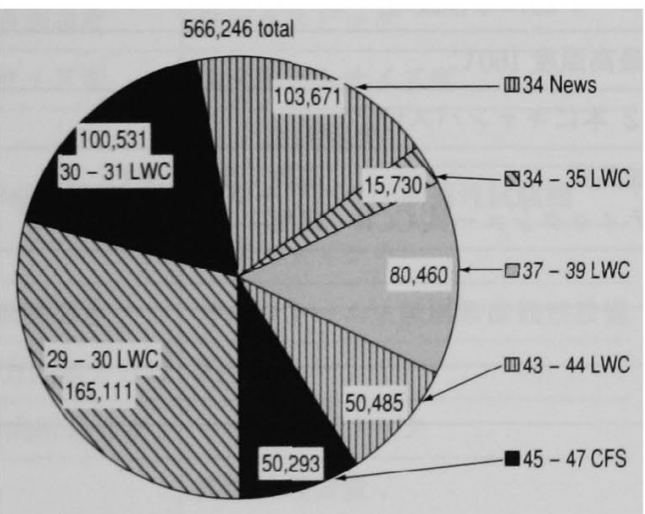

図 2 坪量別コート紙消費割合 （米国 単位 $L b / 3,300 \mathrm{ft}^{2}$ ，及び short tons）
パソコン雑誌等の情報誌向けとして, 軽量, 超軽量微 塗工紙（LWC，ULWC）の消費量が増加している。 この傾向は海外でも見られ，図 2 に示した米国におけ る 1999 年のテキスト向け塗工紙消費動向 ${ }^{1}$ では, 坪量 $43 \sim 46 \mathrm{~g} / \mathrm{m}^{2}\left(29 \sim 31 \mathrm{Lb} / 3,300 \mathrm{ft}^{2}\right)$ のLWC, LWC の消費量が全体の $50 \%$ 弱を占めている。

以上に示した市場動向から，紙コータに対する最近 の市場ニーズは,「高速化」「軽量・微塗工化」に向っ ているものと考えられる。

\section{3. 三菱パイロットコータの高速化と仕様}

前述のような「高速化」「軽量・微塗工化」といっ た市場ニーズに対応するため，当社ではパイロットコ 一タの高速化改造工事を行った。図 3 及び表 1 は, 改 造後におけるパイロットコータのレイアウト及び仕様 について示したものである。表 1 に示したように，高 速化に対応するため,

(1)ドライブ能力の增強とセクショナル化

(2)テンション制御・加減速の自動化

(3)アンワインタ/リール最大巻取り径の大径化

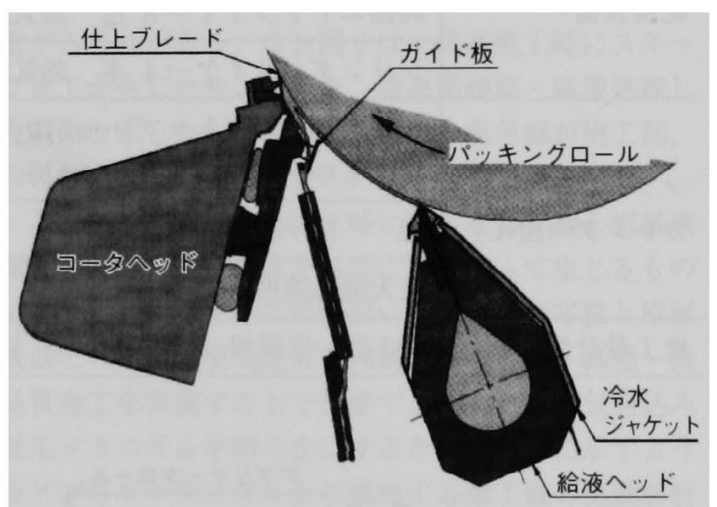

図 4 S-FLOW コータ

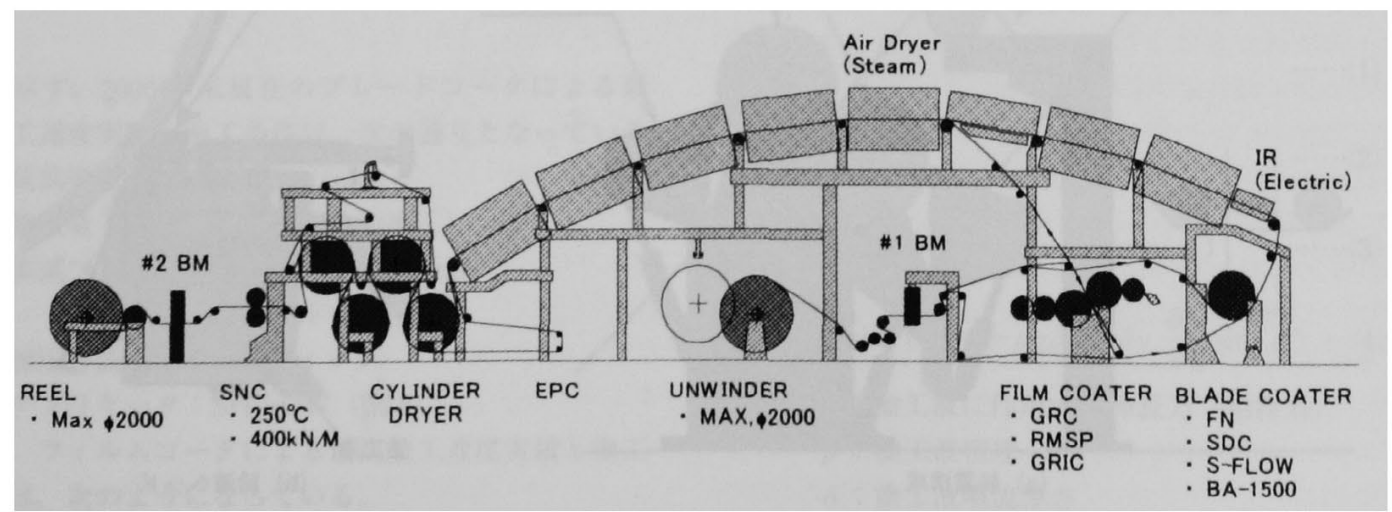

図 3 三菱パイロットコータ 
(4)フィルムコータステーションのレイアウト変更 を行い, 最高整工速度 $2,800 \mathrm{~m} / \mathrm{min}$ (ブレードコー タ,フィルムコータとも), 最大加減速率 $30 \mathrm{~m} / \mathrm{min} / \mathrm{sec}$, 卷取り最大直径 $2,000 \mathrm{~mm}$ で運転することが可能とな っている。
なお(4)は, 軽量・微塗工向け²)としてのゲートロー ル，ロッドメタリングなどを用いたピグメント塗工テ スト，及びサイズ塗エテストが，高速で安定して実施 できるようにしたものである。

次に，このパイロットコータを用いた塗工実績につ

表 1 三菱パイロットコータの仕様

\begin{tabular}{|c|c|}
\hline 項 & 様 \\
\hline 駆動能力 & $150 \sim 2,800 \mathrm{~m} / \mathrm{min}$ \\
\hline 紙幅 & 標準 $800 \mathrm{~mm}$ 塗工可能紙幅 500 $850 \mathrm{~mm}$ \\
\hline テンション制御 & ロードセルによる自動制御 \\
\hline 加减速率 & 最大 $30 \mathrm{~m} / \mathrm{min} / \mathrm{sec}$ \\
\hline プレードコータ & $\begin{array}{l}\text { ブレード形式…゙ベルブレード，ベントブレード } \\
\text { アプリケータ形式‥FN, SDC, S-FLOW, BA-1500 }\end{array}$ \\
\hline フィルムコータ & $\begin{array}{l}\text { GRC, RMSP, GRIC …片面塗工 } \\
2 \text { ロールサイズプレス‥画面同時塗工 }\end{array}$ \\
\hline \multirow{3}{*}{ 乾燥設備 } & 電気式 IR ト゚ライヤ $\cdots 1$ 台 フィルムコータ部にも移設可 \\
\hline & 両面エアドライヤ $\cdots 8$ 台 蒸気式 最高温度 $160^{\circ} \mathrm{C}$ \\
\hline & シリンダドライヤ $\cdots 4$ 本 蒸気式 2 本にキャンバス付 \\
\hline \multirow{3}{*}{$\begin{array}{l}\text { ソフトニップ } \\
\text { カレンタ (SNC) }\end{array}$} & 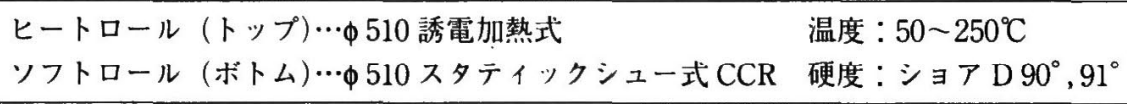 \\
\hline & 線 压 $\cdots 30 \sim 400 \mathrm{kN} / \mathrm{m}$ \\
\hline & 最大通紙速度 $\cdots 1,500 \mathrm{~m} / \mathrm{min}$ \\
\hline 㳂工量計測 & $\mathrm{BM}$ 計…原紙用/塗工紙用 各 1 台 \\
\hline
\end{tabular}

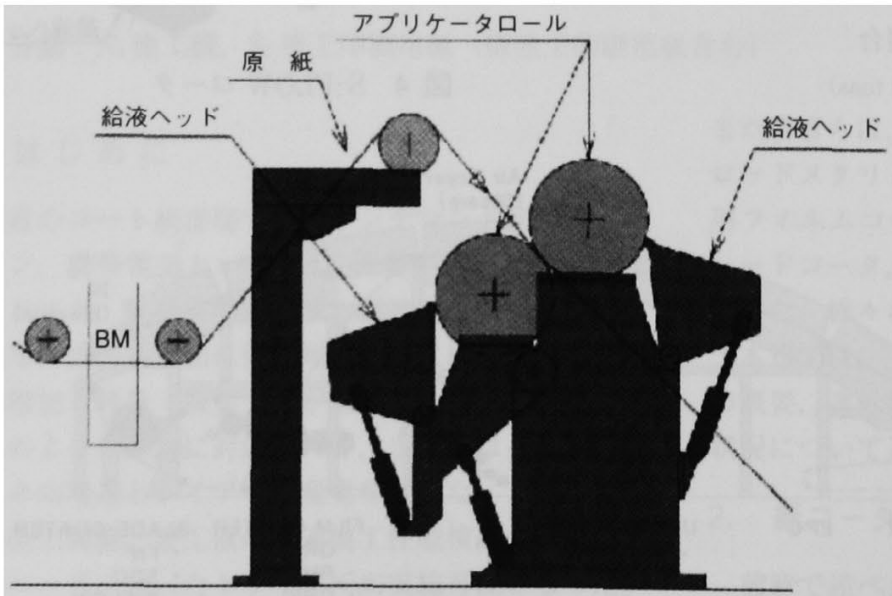

(a) 装置構成

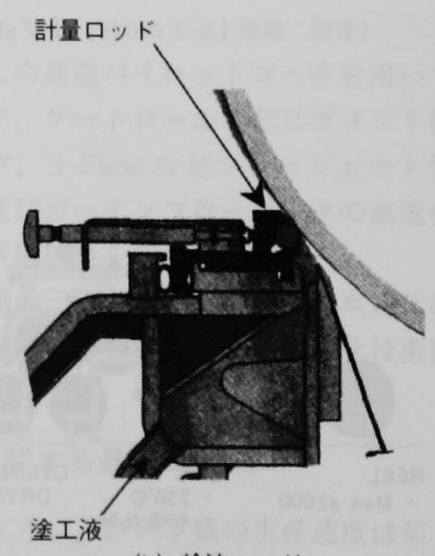

（b）給液ヘッド

図 5 フィルムコータ (ロッドメタリング) 
表 2 紙品質評価設備

\begin{tabular}{|c|c|}
\hline 項 目 & 測 定 機 器 \\
\hline \multirow{2}{*}{ 平滑度 } & ベック式平滑度計 \\
\hline & レーザ変位計（2 次元表面粗度） \\
\hline \multirow{2}{*}{ 紙 厚 } & 紙厚計（平板式） \\
\hline & レーザ変位計（2 次元紙厚分布） \\
\hline 白色度 & ハンター白色度計 \\
\hline 光沢度 & 村上式光沢度計 \\
\hline 透気度 & ガーレ透気度計 \\
\hline \multirow{6}{*}{ 塗工液粘度 } & $\mathrm{B}$ 型粘度計 \\
\hline & ハーキュレス粘度計 \\
\hline & キャピラリ粘度計 \\
\hline & ハーケ粘弾性計 \\
\hline & コーンプレート粘弾性計 \\
\hline & レオペキシーアナライザ \\
\hline 表面強度 & ワックスピック \\
\hline サイズ度 & ステキヒトサイズ度 \\
\hline \multirow{3}{*}{ 印刷試験機 } & RI 印刷試験機 \\
\hline & プルーフパウ印刷適性試験機 \\
\hline & クロータインキ \\
\hline 紙層構造 & ミクロトーム十紙層断面観察設備 \\
\hline 紙厚方向成分分析 & EPMA \\
\hline$Z$ 方向有分分布 & シートスプリッタ \\
\hline その他 & $\begin{array}{l}\text { 画像処理装置 } \\
\text { （透過光/反射光均一性評価など） } \\
\text { 印刷品犋評価設備 }\end{array}$ \\
\hline
\end{tabular}

いて示す。2000 年末現在のフレードコータによる最 高塗工速度実績と染工条件は, 次の通りとなっている。

- 最高塗工速度 : $2,600 \mathrm{~m} / \mathrm{min}$

·塗工量 $\quad: 9 \mathrm{~g} / \mathrm{m}^{2}$ (片面染工)

・供試ブレード : $76 \mathrm{~mm} \times \mathrm{t} 0.508 \mathrm{~mm}$ フレード角 $45 \mathrm{deg}$

-加压方法 : S マティック

・アプリケータ:S-FLOW（図 4)

また,フイルムコータによる最高塗工速度実績と塗工 条件は、次のようになっている。

- 最高塗工速度 : $\mathscr{Z}, 500 \mathrm{~m} / \mathrm{min}$
- 整工量 $: 9 \mathrm{~g} / \mathrm{m}^{2}$ (片面塗工)

・コータ形式 : ロッドメタリング

（実機概略 図 5)

なお,このパイロットコータで塗工したサンプルの品 質評価は，表 2 に示す機器などで行っている。

\section{4. 高速塗工時の課題と取組み}

本章では，パイロットコータを用いた高速玨工試験 において経験した技術的課題と，これに対する当社の 取組み，及び新技術について述べる。

4.1 ブレードコータの高速化技術

近年，塗工速度の高速化と高品質化に対応するため, フレードコータのアプリケータにはフリージェット型 （S-FLOW など）が多く採用されている。このアプリ ケータを用いた $2,000 \mathrm{~m} / \mathrm{min}$ 以上の高速塗工では, 下記のような現象が問題となる゙”。

（1）塗工液噴流と原紙表面間への空気巻込みによる 転写膜の乱れ

（2）遠心力による転写液膜の飛散（スプラッシュ） 上記の現象は, 塗工面のオレンジピール, ピンホー ル，及び図6に示すスキップ望工といった塗工不良に 慗がる恐れがある。なお図 6 は，高速塗工時にスキッ プ塗工が生じたサンプルを，透過光観察・画像処理し た結果を示したものであり，図中の黒色部が塗工部， 白色部がスキップ（非塗工）部を示している。

これらの現象は高速塗工時に塗工液転写膜と原紙表 面との間へ空気が巻込まれることによって生じるもの であるため，高速塗工時において叙工液転写膜と原紙 表面との間への空気侵入を抑制することは，高速・高 品質塗工を実現する上で重要である。この空気巻込み 発生メカニズムを明らかにするため，図７に示すよう なアプリケータノスルから噴出する塗工液の流動解析 を行った。

解析に用いた基䃈方程式は，次式の通りである。

$$
\begin{array}{ll}
\frac{\partial(\delta \mathrm{v})}{\partial \mathrm{s}}=0 & \cdots \cdot(1) \\
\mathrm{F}=4 \delta \eta \frac{\partial \mathrm{v}}{\partial \mathrm{s}} & \cdots \cdots(2) \\
\frac{\partial}{\partial \mathrm{s}}[\mathrm{F} \cos (\theta)]=\rho \delta \mathrm{v} \frac{\partial \mathrm{v}}{\partial \mathrm{s}} \cos (\theta) & \cdots \cdots(3) \\
\frac{\partial}{\partial \mathrm{s}}[\mathrm{F} \sin (\theta)]=-\rho \mathrm{g} \delta-\rho \delta \mathrm{v} \frac{\partial \mathrm{v}}{\partial \mathrm{s}} \sin (\theta) & \cdots(4)
\end{array}
$$

但L, F：途工液に作用する伸長力（粘性力）

$$
\begin{aligned}
& \rho: \text { 染工液密度 } \\
& \delta: \text { 染工液喷流厚さ } \\
& \mathrm{v}: \text { 染工液流速 }
\end{aligned}
$$




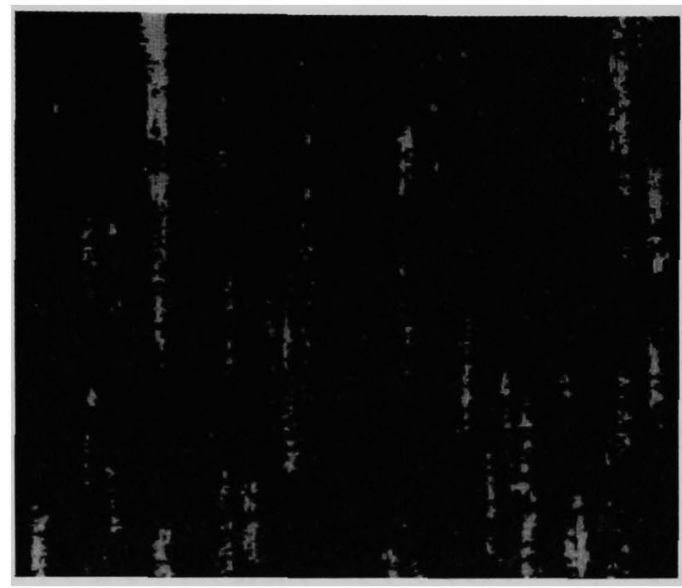

図 6 スキッブ塗工

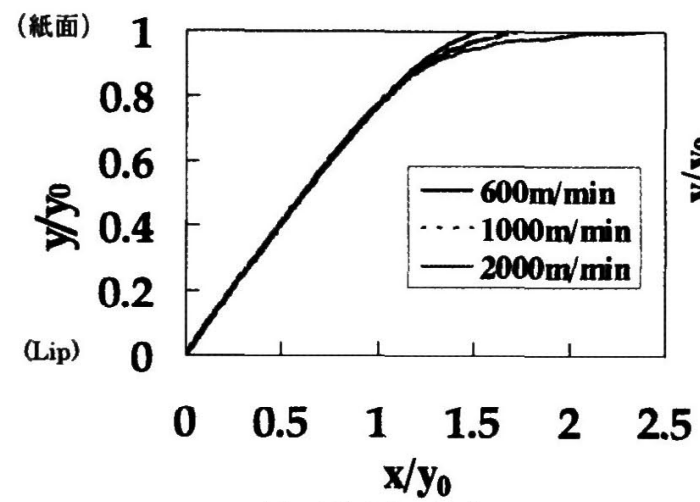

(a) 啨流全体の勒跡

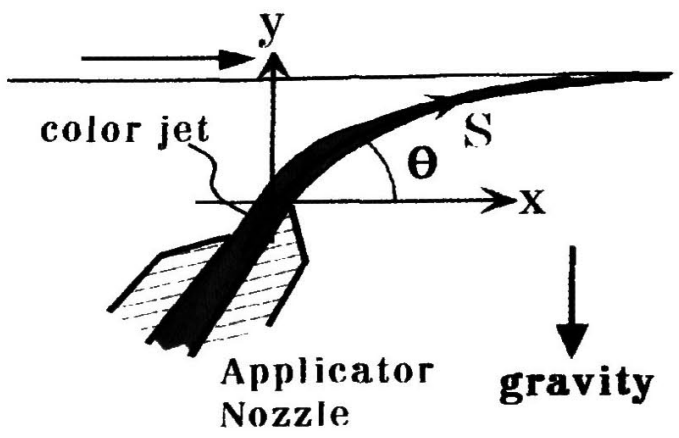

図 7 染工液噴流解析モデル

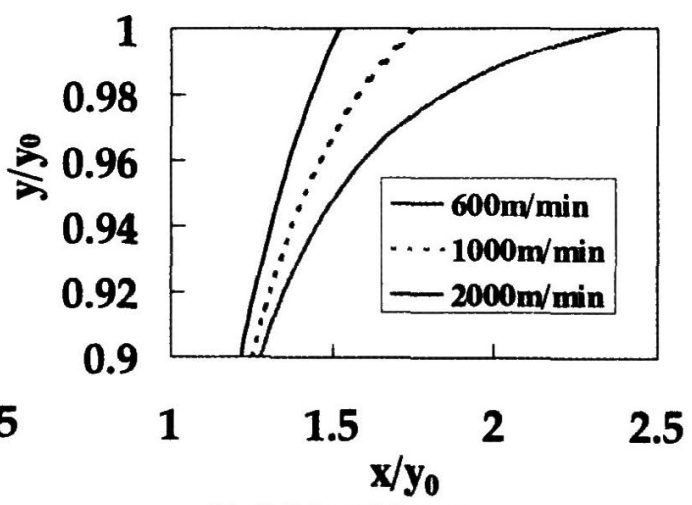

(b) 接液位置近傍の軌跡

図 8 準工液噴流の軌跡解析結果

\section{その他の定義は図 7 参照}

图 8 に，染工液粘度 2 Pasec，転写膜厚 $150 \mu \mathrm{m}$ の 場合における染工液噴流の形状を計算した結果につい て示す。図8(a)はアプリケータリッフ先端から原紙に 粱工液噴流が接する位置（以下「接液位置」と称す） までの渠工液噴流軌跡を，(b)は接液位置近傍の染工液 做流軌跡を，それぞれアプリケータノズルリップから 原紙表面までの垂直方向距離 $\mathrm{y}_{0}$ で無次元化して示し ている。

図8に示したように, 染工液噴流は染工速度の增加 に伴って通紙方向下流側に引張られ，接液位置におい て粱工液噴流と原紙表面とが形成する動的接液角が鋭 角になる。このような鋭角のくさび形空間が形成され た結果，接液位置におけるくさび形空間の空気圧力が 潤滑理論に従って上䄯し, 空気巻込みが生じるものと 考えられる。

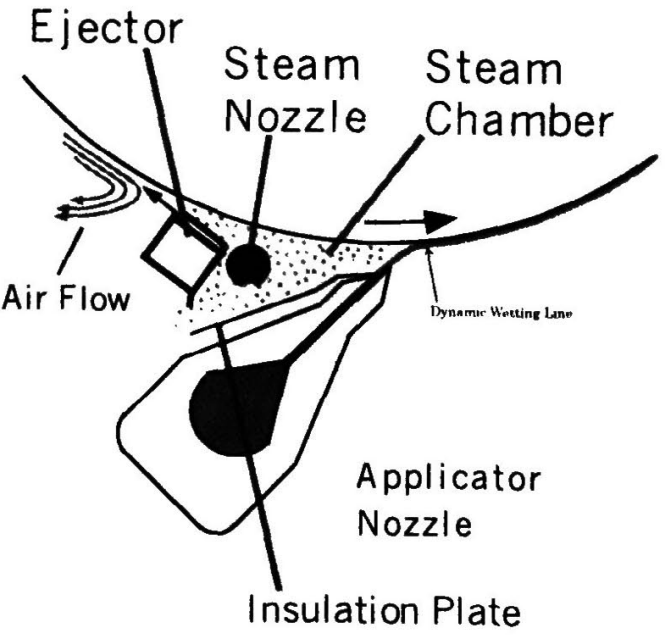

図 9 蒸気置換シールシステム 


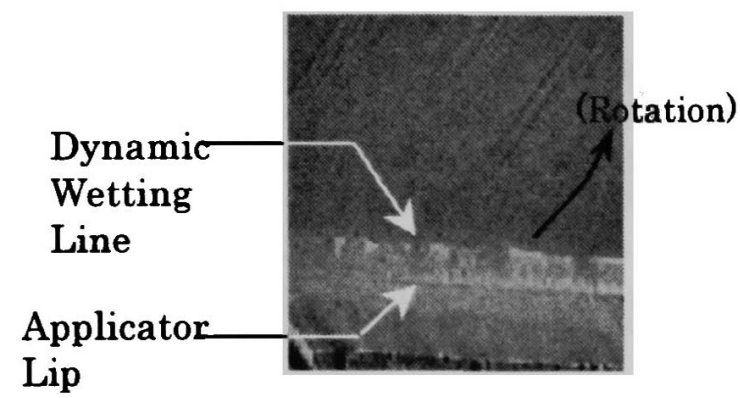

(a) 蒸気置換シールシステム無

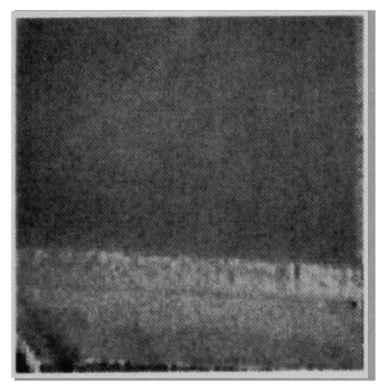

(b) 蒸気置換シールシステム有

図 10 蒸気置換シールシステムによる動的接液線の変化

このようなメカニズムによって発生する空気巻込み を避けるため, 図9に示すような「蒸気置換シールシ ステム」を開発しだの1。このシステムでは, 原紙上 の同伴空気境界層を、「エゼク夕」と称する対向空気 噴流で除去した後, 接液位置近傍のくさび形空間内の 空気を叙工液に可溶な水蒸気に置換する。空気と置換 された水蒸気は, くさび形空間内で凝縮して負圧を発 生し, この負圧によって塗工液噴流を通紙方向上流側 に引き戻す。この塗工液噴流の引き戻し作用によって， 接液位置における塗工液の動的接触角を鈍角にし, く さび形空間の圧力上昇を抑制する効果を示す。さらに, 空気と置換された水蒸気が転写液膜と原紙表面の間に 巻込まれても, 凝䈹水は塗工液に溶け込むか, 速やか に原秪内に浸透するため，塗工品質に影響を及はささな い。

この蒸気置換シールシステムを適用した場合におけ る動的接液線の可視化結果を，図 10 に示す。図 10 の うち(a)は蒸気置換シールシステムが無い場合，(b)は蒸 気置換シールシステムが有る場合を，それぞれ示して いる。なお, 撮影時の塗工速度は $2000 \mathrm{~m} / \mathrm{min}$, 転写 膜厚は $75 \mu \mathrm{m}$ である。図に示したように, 蒸気置換 シールシステムの無い(a)の動的接液線は, 紙幅方向に 乱れて不均一となっている。これに対し, 蒸気置換シ ールシステムを適用している(b)の動的接液線は紙幅方 向に一様になっている。この時, 動的接液線の時間的 変動も大幅に減少していることがビデオ撮影画像によ り確認された。

以上に述へた蒸気置换シールシステムを採用するこ とにより, 動的接液線が安定化し, 空気巻込みに起因 するスキップ, スブラッシュなどの問題のない, 安定 した高速塗工が実現できることを，高速パイロットコ ータを用いた塗エテストで検証した。

\section{2 フィルムコータ高速化への取組み}

フィルムコータは微塗工紙から軽量コート紙への対
応性に優れている。このフィルムコータで高速高品質 塗工を実現するため, 近年アプリケータロールニップ 出側で発生するミスティンク現象に関する研究が盛ん に行われている゙。

ミスティング現象の発生メカニズムは,一般に以下 のようなものと説明されている゙。即ち,

・アプリケータロールニップ出側で塗工液膜が分裂 する際に塗工液の「系引き (filament formation)」 が発生し,

・これがちぎれる際に糸引きの一部がミストとなっ て飛散する。

このようなミスト発生メカニズムを確認するため, 著者らはパイロットコータを用いて実際の紙用塗工液 でミスティングが発生する様子の可視化を試みた。奏 験条件は以下の通りである。

・アプリケータロール周速： $600 \mathrm{~m} / \mathrm{min}$

・アプリケータロール上液膜厚 $: 15 \mu \mathrm{m}$

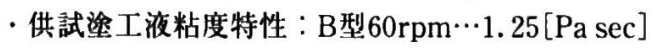

図 11 にその結果を示す。図 11 に示したように、ミ スティング現象は, 明らかに塗工液膜分裂時の糸引き が朤㗒することによって発生していることが確認され た。

図 12 は, 紙なし（ロール転写）テストで計測した アプリケータロール上の㓌工液膜厚に対するミスト発 生量を、アプリケータロール周速別に示したものであ

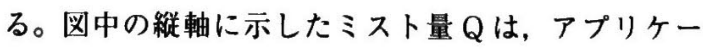
タロール上に形成されている塗工液膜の流量 $(\delta=$ 塗 工液膜厚さ， $U=$ ロール周速）で無次元化して示して いる。また凡例中の数字は, アプリケータロール周速 $(\mathrm{m} / \mathrm{min})$ を示している。なお塗工液の固形分濃度は 60.5 重量\%である。

図 12 に示したように, ミスト発生量は,ロール状 の塗工液膜厚およびアプリケータロール周速の增加に 伴って急激に增加する傾向を示している。 


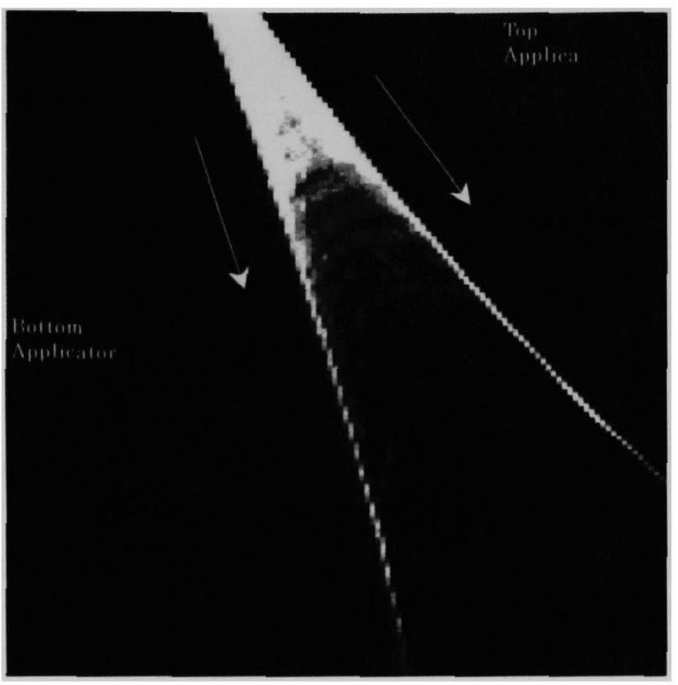

図 11 ニップ出側での糸引き

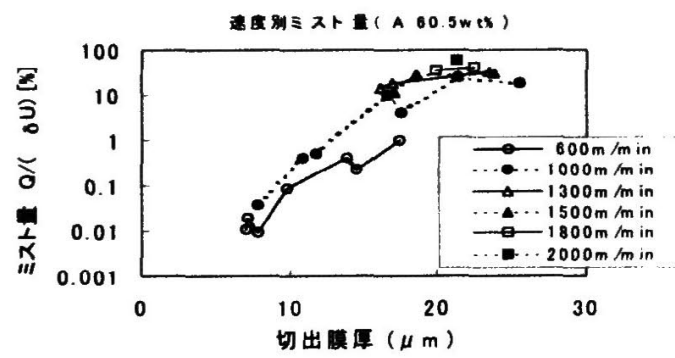

図 12 ミスト発生量計測結果例
このように，現在暼社では，フィルムコータによる 高速・高品質塗工のための研究・開発, 即ちミスト発 生特性把握とメカニズム解明のための基磼デー夕収集, および対策案の検証テストを精力的に推進している。 今後更に研究を重ね, 高速・高品質塗工を実現するフ イルムコータを近々市場投入する所存である。

\section{5. まと め}

以上，三菱パイロットコータ高速化の概要と，これ を用いた紙コータ高速化に関する研究・開発について ご紹介した。今後, 更に市場ニーズにマッチしたコー 夕の開発を推進してゆく所存であり, 皆様のご意見, ご協力をお願い申し上げます。

\section{参考文献}

1) McCann. R., Proc. 2000 TAPPI Coating Conf. And Trade Fair (May, '00), p 3.

2）例えば Dickson, R., et. al., Proc. 2000 TAPPI Coating Conf. and Trade Fair (May, '00), p 167.

3) Roper III, J. A., et. al., Proc. 1999 TAPPI Coating Conf.

4）杉原ほか，実案 2532902

5）杉原ほか、特願平 6-218313

6）杉原ほか，特願 2000-100924

7）例えば Roper III, J. A., T APPI J. vol. 82 No. 1 （Jan. '99), p 231.

8）例えば Fernando, R. H., Proc. 1999 TAPPI Advanced Coating Fundamentals Symp. ('99), p 99. 


\section{紙パルプ産業の歴史・特徴とエコロジー}

\section{紙パルブ技術協会 飯田 清昭}

日本の製紙産業は，恵まれない立地条件にもかかわらず，生産量は世界第 2 位で，国内経済の中でも 重要な地位を占めている。これは, 製紙産業が資本, 原料, 生産技術, 環境等の問題に挑戦的に取り組 のできた桔果である。この報告では，そのいくつかの努力を紹介すると共に，製紙産業の歴史・特徵を 概説する。

今啳も，製紙産業は幾多の新しい問題に直面するであろう。それを切り開くのは，若い世代の柔軟な 挑戦的な取り組みで，それに産莱の将来が託される。

(本文1ベージ)

\section{三菱コータ高速化への取組み}

\section{三萲重工亲株式会社 技術本部広島研究所 杉原 正浩, 山田 建治 紙印刷機械事夈部 三浦 洋司，宮合 敏明}

最近のコート紙市場における塗工速度の増加と軽量・微塗工化の動向に对応すべく，当社ではパイロ ットコータの增速改造とレイアウト変更を行った。これにより, 渠工速度 $2,800 \mathrm{~m} / \mathrm{min}$ での各種工 装望, 染工湤の高速塗工性能検証・評洒など, 各種ニーズに合ったトライアルが実施可能となった。ま た著者らは，この高速バイロットコータを用いて，ロッドメタリンク，ゲートロールなどピグント塗 工用フィルムコータ, S-Flow などフリージェット型ブレードコータ, 及びカーテンフローコータの高 速化に向けた，漛々な技術開発を行っている。高速フリージェット型アプリケータ及び高速カーテンフ ローコータの開発においては，塗工液ジェットの流動解析を行い，塗工液膜と原紙との間に空気が侵入 するメカニスムを明らかにすると共に，接液部における空気侵入により発生するスキッフ、スブラッシ ユを抑制する「蒸気置換シールシステム」を新たに開発した。一方，ゲートロール，ロッドメタリンク などフィルムコータの開発においては, アプリケータロール上の塗工淮膜が原紙表面に転写されるロー ルニップ出侧で発生するミスティング現象について, その発生メカニスムとミスト発生量特性について 把握し，これを基に高速フィルムコータの開発を行っている。

本報では，上迈の三菱バイロットコータ高速化改造の概要，運転経倹，及び各種コータの高速化技術 開発状況について紹介する。

(本文 12 ページ)

\section{オプティコンセプトによる最新の洋紙用抄紙機}

\section{住友重機械工業株式会社 機械事業本部 田頭 弘章}

上質コート紙は，原紙の生産と仕上げ加工を分けて行うオフマシン方式でほとんどが生産されている。 オフマシン方式には，原紙生産と仕上げ工程が独立しているため各工程毎に最適化を図り易いという特 長がある一方, 各程毎に専任のオペレータを必要とするため操業員の数が多い, 設㯰スペースが大き 